\title{
Helpful Organizations: Membership in Inter- Governmental Organizations and Environmental Quality in Developing Countries
}

\author{
GABRIELE SPILKER*
}

Does membership in intergovernmental organizations help developing countries enhance their environmental performance? This article argues that IGO membership can improve the environmental performance of developing countries, by linking different issues, promoting the general idea of environmental sustainability and providing a channel through which these countries receive technologies and resources necessary to reduce pollution. This argument has been tested on panel data for 114 developing countries in 1970-2000. The results confirm that, controlling for a country's income and its political system, IGO membership is indeed associated with a reduction in both air pollution and greenhouse gases. To understand the mechanisms behind this result better, IGO membership is disaggregated according to both function and the degree of institutionalization of the respective organization.

Does integration into the international system help developing countries enhance their environmental performance? Although industrialized countries still account for the bulk of environmental pollution, emissions generated in developing countries have increased significantly over recent years. For example, a recent report by the International Energy Agency (IEA) states that carbon dioxide $\left(\mathrm{CO}_{2}\right)$ emissions by developing countries 'increased at a much faster rate' than $\mathrm{CO}_{2}$ emissions by industrialized countries. ${ }^{1}$ It is thus crucial to understand which factors have the potential to slow the increase in pollution in developing countries, contributing to national and global sustainability.

The existing literature pays considerable attention to the effects of income, democracy and economic openness when explaining variation in the environmental performance of both industrialized and developing countries. ${ }^{2}$ I argue that membership in intergovernmental organizations (IGOs) improves the environmental performance of

* ETH, Zurich (email: Gabriele.spilker@ir.gess.ethz.ch). For detailed suggestions and comments, the author thanks Thomas Bernauer, Xun Cao, Erik Gartzke, Simon Hug, Anna Kalbhenn, Vally Koubi, Lena Schaffer and the Journal's Editor, Hugh Ward, as well as its anonymous reviewers, for detailed suggestions and comments. This article was written in the context of the National Center for Competence in Research (NCCR), 'Democracy in the 21st Century'.

1 (IEA) International Energy Agency, 'CO2 Emissions from Fuel Combustion - Highlights', IEA Statistics (2009), p. 10. According to the IEA for developing countries, power generation and transport, the two main contributors to global $\mathrm{CO}_{2}$ emissions, increase by three times and by one and a half times than the global average between 1990 and 2007 - see IEA, 'CO2 Emissions from Fuel Combustion Highlights', p. 16.

2 Eric Neumayer, 'Does Trade Openness Promote Multilateral Environmental Cooperation?' World Economy, 25 (2002), 815-32; Hugh Ward, 'Liberal Democracy and Sustainability', Environmental Politics, 17 (2008), 386-409; Michèle Baettig and Thomas Bernauer, 'National Institutions and Global Public Goods: Are Democracies More Cooperative in Climate Change Policy?' International Organization, 63 (2009), 281-308. 
developing countries because IGOs can provide them with much needed resources in the form of knowledge and technology necessary to curb pollution. Furthermore, IGOs can constitute a forum in which actors having an interest in environmental quality may successfully influence other countries' behaviour. Finally, in addition to increasing the reputational stakes for reneging on agreements, IGOs also allow for issue linkage.

I test these propositions empirically using time-series cross-section analysis of 114 developing countries from 1970 to 2000. The results confirm that IGO membership is indeed associated with a reduction in both air pollution and emissions of greenhouse gases. Moreover, I find that, whereas an increase in income leads to higher emissions, the type of political regime does not have any effect on environmental performance in developing countries. ${ }^{3}$

To understand the mechanisms behind the strong effect of IGO membership on developing countries' environmental performance better, I disaggregate IGO membership on the basis of function and degree of institutionalization. Surprisingly, it is not membership in environmental IGOs that drives the results. Rather, it is membership in umbrella, nuclear, economic general and military organizations that is conducive to improved environmental performance in less developed countries. A possible explanation is that these types of organizations, by disseminating information, providing technological and financial resources and successfully linking different issues, enhance the capacity of developing countries to provide environmental quality.

While some degree of formalization or institutionalization of an organization is needed to affect environmental quality in developing countries, interestingly, those organizations that can constrain their member countries' behaviour the most are not necessarily the most effective ones. With regard to $\mathrm{CO}_{2}$ emissions, the effect of moderately institutionalized organizations is more pronounced than the effect of the most institutionalized ones. A possible explanation is that technology and knowledge transfer, issue linkage and broader socialization processes might work well as long as the organization possesses at least some degree of institutionalization.

The implications of this article are twofold: first, international integration should not be reduced to trade openness ${ }^{4}$ and capital mobility, since other important characteristics of the international system, such as membership in IGOs, seem to affect environmental performance in important ways. Indeed, this article finds that trade openness and foreign investment are not systematically associated with a reduction in emissions, whereas IGO membership is always connected with improvements in environmental quality. Second as the type of the political regime does not seem to play a significant role in the environmental performance of developing countries, tying them into a strong system of international organizations might be a fruitful way forward.

The following section develops the theoretical argument and outlines the hypotheses to be tested. Next, the data and methods used are described, and the results of the empirical analysis are presented. The final section summarizes the findings and discusses the theoretical and policy implications.

${ }^{3}$ Cf. Eric Neumayer, 'Do Democracies Exhibit Stronger International Environmental Commitment? A Cross-Country Analysis', Journal of Peace Research, 39 (2002), 139-64; Robert T. Deacon, 'Dictatorship, Democracy, and the Provision of Public Goods' (University of California, Santa Barbara, Working Paper, 2003), 1-57.

${ }^{4}$ Werner Antweiler, Brian R. Copeland and M. Scott Taylor, 'Is Free Trade Good for the Environment?', American Economic Review, 91 (2001), 877-908. 
THEORETICAL FRAMEWORK

The theoretical argument is structured in three parts. First, the effect of IGO membership is analysed by emphasizing two main channels through which IGO membership can alter environmental quality in developing countries. On the one hand, I argue that integration into the international system can enhance the willingness of developing countries to improve their environmental performance through issue linkage and the diffusion of environmental interest. On the other hand, it can augment the capability of developing countries to foster environmental quality through the flow of resources in the form of knowledge and improved technologies. Second, following the logic of the Environmental Kuznets Curve, I present arguments suggesting that, in the case of developing countries, an increase in national income should be associated with a decrease in environmental quality. Third, drawing on the literature dealing with the relationship between the political system and the provision of public goods, I posit that the political system should not have an independent effect on environmental quality in developing countries. This implies that democratic developing countries should not be characterized by better environmental performance relative to their autocratic counterparts.

\section{Membership in International Organizations}

Most of the literature on international integration and the provision of environmental quality focuses solely on economic facets of international integration, such as trade ${ }^{5}$ and foreign direct investment (FDI). ${ }^{6}$ Few studies have taken the political dimension of globalization into account. A notable exception is that by Ward, who examines whether countries that are more central to the network of international environmental regimes act more sustainably at the national level. ${ }^{7}$ Using social network analysis, he finds that more central countries indeed care more about domestic environmental quality. Although his study concentrates on the network of international environmental treaties and organizations, he notes:

the Kantian view is that IGOs, economic interdependence and democracy form a mutually supportive triangle that promotes peace. The network of IGOs facilitates deterrence of bad behaviour, mediation and problem-solving, sharing of information and the generation of norms and trust. ${ }^{8}$ This raises the possibility that nations' environmental records may relate to their general position in the international system, just as recent work suggests that joint membership of non-trade-related IGOs increases trade between pairs of nations. ${ }^{9,10}$

\footnotetext{
5 Antweiler, Copeland and Taylor, 'Is Free Trade Good for the Environment?'; Jeffrey A. Frankel and Andrew K. Rose, 'Is Trade Good or Bad for the Environment? Sorting out the Causality', Review of Economics and Statistics, 87 (2005), 85-91.

${ }^{6}$ Muthukumara Mani and David Wheeler, 'In Search of Pollution Havens? Dirty Industry in the World Economy, 1960-1995', Journal of Environment and Development, 7 (1998), 215-47; Matthias Busse, 'Trade, Environmental Regulations and the World Trade Organization', in World Bank Policy Research Working Paper 3361 (Washington: World Bank, 2004), 1-30.

${ }^{7}$ Hugh Ward, 'International Linkages and Environmental Sustainability: The Effectiveness of the Regime Network', Journal of Peace Research, 43 (2006), 149-66.

${ }^{8}$ Bruce Russett and John Oneal, Triangulating Peace: Democracy, Interdependence and International Organizations (New York: W. W. Norton, 2001).

9 Paul Ingram, Jeffrey Robinson, and Marc Bush, 'The Intergovernmental Network of World Trade: Igo Connectedness, Governance, and Embeddedness', The American Journal of Sociology, 11 (2005), $824-858$,

${ }^{10}$ Ward, 'International Linkages and Environmental Sustainability', p. 154.
} 
Following Ward, I propose to analyse the impact of IGO membership on a country's willingness to take care and capability of taking care of its environment. Thereby, I evaluate whether the inclusion of the political aspect of international integration, in addition to the economic facets of globalization, adds to our understanding of environmental quality in developing countries.

The general purpose of intergovernmental organizations ${ }^{11}$ is to facilitate co-operation at the international level and thereby enable countries to solve problems that they often are unable to solve independently, thus realizing benefits from mutual co-operation. ${ }^{12}$ IGOs promote co-operation by reducing transaction costs, decreasing uncertainty, strengthening the shadow of the future, increasing reputational costs and by allowing credible commitments. ${ }^{13}$ Consequently, I argue that membership in IGOs may influence the environmental performance of developing countries for the following reasons: ${ }^{14}$

(1) At least in principle, IGOs can compel member states to obey their rules by raising the reputational stakes for reneging on agreements. ${ }^{15}$ In addition, many IGOs establish non-compliance procedures such as sanctions that can help enforce conformity with the rules of the organization. Note, however, that this will directly affect environmental quality only in the case of IGOs that have some environmental purposes, such as the Multilateral Fund for the Implementation of the Montreal Protocol or the North Atlantic Salmon Conservation Organization.

(2) IGOs create norms defining good behaviour - or rather what constitutes bad conduct. ${ }^{16}$ Although a specific IGO might not have been created with an explicit environmental mandate, the broader idea of environmental protection as being of importance might still spread through membership in this IGO. In this sense, international organizations can constitute a forum in which states and other actors that have an interest in environmental protection, such as environmental non-governmental organizations (ENGOs), can promote this idea and also influence other states. Hence, IGO membership can be important to socializing states in relation to environmental protection.

A pertinent example is sustainable development. In the last two decades many IGOs have taken up this issue. Although not all of these organizations actually provide developing countries with relevant technologies and resources, they increase both domestic awareness and international pressure for sustainable development. IGOs such as

11 According to Jon Pevehouse, Timothy Nordstrom and Kevin Warnke, 'Intergovernmental Organizations. 1815-2000: A New Correlates of War Data Set. Version 2.1' (2004), an IGO is an organization that consists of at least three members of the $\mathrm{COW}$-defined state system, holds regular plenary sessions at least once every ten years, and possesses a permanent secretariat and corresponding headquarters. According to this definition, IGOs are formalized forms of international co-operation.

12 Robert Keohane, After Hegemony: Cooperation and Discord in the World Political Economy (Princeton, N.J.: Princeton University Press, 1984).

${ }^{13}$ Keohane, After Hegemony; Kenneth W. Abbott and Duncan Snidal, 'Hard and Soft Law in International Governance', International Organization, 54 (2000), 421-56.

14 Although some arguments about the way that IGO membership could serve to increase environmental quality should hold for both industrialized and developing countries alike, this is not the case for all arguments.

15 Keohane, After Hegemony.

16 Ward, 'International Linkages and Environmental Sustainability'; Oran R. Young and Marc A. Levy, 'The Effectiveness of International Environmental Regimes', in Oran R. Young, The Effectiveness of International Environmental Regimes: Causal Connections and Behavioral Mechanisms (Cambridge, Mass.: MIT Press, 1999). 
the Organization of American States or the African Union are examples of organizations that have passed declarations devoted to sustainable development, and the former has even established a department dealing with this issue, besides embracing the promotion of environmental quality. ${ }^{17}$

This effect of IGO membership is also emphasized in the literature on policy diffusion. Cao, for example, shows that interactions at the international level through trade ties or connections in IGO networks, which serve as channels for information transfer, play a significant role in the socialization process among states. ${ }^{18}$

(3) Even though countries become members of an IGO for specific reasons, e.g. financial assistance, they are also exposed to the other purposes of the organization, such as environmental protection. Examples include the World Bank and the European Union (EU). Jahn, for instance, posits that 'membership in an international organization such as the EU may support the improvement of environmental standards. The rationale is that particular environmentally conscious countries take the role of pioneers that push environmental issues onto the agenda of countries that might be perceived as environmental laggards'. ${ }^{19}$ The case of Laos corroborates this argument. By joining the Association of Southeast Asian Nations (ASEAN) in 1997, Laos was required to implement a number of agreements pertaining to making agri-economic development more sustainable, which as a side effect positively affected Laos's environment. ${ }^{20}$

The three arguments above all refer to mechanisms through which IGOs might influence a country's willingness to enhance its environmental performance. In this sense, these arguments can equally pertain to both developing and developed countries. However, an additional argument suggests that membership in IGOs may especially affect the capability of developing countries to improve their environmental performance by allowing for information and technology transfer. This channel is especially important since developing countries often lack the necessary resources and technologies to combat environmental degradation. ${ }^{21}$ Porter et al. argue that new information and knowledge about environmental pollution can create awareness of environmental quality as an important public good, and knowledge about technology for abatement could be

17 This trend is also becoming evident in the lending behaviour of major development aid actors such as the World Bank. For example, countries applying for loans with the International Development Association (IDA), which is the part of the World Bank that provides loans to the poorest developing countries, are obliged to provide a National Environmental Action Plan, which outlines a country's major environmental problems and describes solutions to mitigate these problems (see Tamar Gutner, 'Explaining the Gaps between Mandate and Performance: Agency Theory and World Bank Environmental Reform', Global Environmental Politics, 5 (2005), 10-37.

18 Xun Cao, 'Networks of Intergovernmental Organizations and Convergence in Domestic Economic Policies', International Studies Quarterly, 53 (2009), 1095-130.

19 Detlef Jahn, 'The Impact of Globalization on Comparative Analysis' (paper presented at the ISA Annual Meeting, New Orleans, 2002), p. 2. This idea is closely related to the concept of issue linkage (Keohane, After Hegemony). In order to achieve co-operation in an environmental issue, benefits in other areas like trade, financial or technological assistance, etc. could be offered to countries that would not be willing to co-operate on environmental issues in general.

20 UNEP, 'State of the Environment Report: Laos', http://www.rrcap.unep.org/pub/soe/index.cfm, (2001).

21 Gareth Porter, Janet Welsh Brown and Pamela S. Chasek, Global Environmental Politics (Boulder, Colo.: Westview Press, 2000); Susmita Dasgupta, Benoit Laplante, Hua Wang and David Wheeler, 'Confronting the Environmental Kuznets Curve', Journal of Economic Perspectives, 16 (2002), 147-68. 
distributed. ${ }^{22}$ This implies that a country that is better 'politically' integrated in the international system could receive more relevant information and could more easily draw on technical knowledge and assistance from international organizations. Examples of IGOs that diffuse information and technologies that also benefit the environment are the World Bank, the Food and Agriculture Organization (FAO) and the World Health Organization (WHO). The World Bank as part of its general 'greening' strategy created, together with some Western governments, the Global Environment Facility (GEF), which aims to provide mainly developing countries with grants and technical assistance to address environmental problems such as climate change, ozone depletion, biodiversity loss and pollution. ${ }^{23}$ Similarly, the FAO's department dealing with natural resource management and environmental issues seeks to promote sustainable land and water use by providing technical assistance and research-driven knowledge on the best ways of achieving sustainable farming and the sustainable management of natural resources. In that way, the organization directly transfers technology and knowledge necessary to reduce environmental pollution to developing countries. Hence, although these organizations mostly pursue goals that are not motivated by environmental protection per se, such as access to safe drinking water and sustainable farming, they also provide technologies and know-how that are often conducive to protecting the environment.

Taken together, these arguments lead to the conjecture that membership in IGOs should positively influence the environmental performance of developing countries:

HYPOTHESIS 1: A developing country that is a member of more IGOs provides higher levels of environmental quality.

However, one could argue that not all international organizations can influence developing countries' environmental performance to the same extent. Gartzke et al. note that IGOs differ with regard to their degree of institutionalization and thus with regard to their 'ability to enact policies and decisions' ${ }^{24}$ Accordingly, the degree of institutionalization of an IGO may partly determine to what extent it has the capability to influence its members. That is, while IGOs whose 'bureaucratic, executive, or judicial organs do not have any formalized power ${ }^{25}$ (minimally institutionalized IGOs) should lack the capability to strongly exert influence over their members, IGOs that 'possess clear mechanisms for coercing or influencing state behaviour ${ }^{26}$ (strongly institutionalized IGOs) could in principle limit member states' sovereignty and thus affect their policies.

Consequently, the influence channels of IGOs discussed above, such as issue linkage or the provision of knowledge and technology, should be more pronounced in those IGOs that are more institutionalized. In contrast, minimally institutionalized IGOs, which lack strong administrative structures and capabilities, might find it harder to provide resources in the form of knowledge and technology needed in developing

${ }^{22}$ Porter, Brown and Chasek, Global Environmental Politics.

${ }^{23}$ Mohamed El-Ashry, 'The Road to Rio: Implications of the UN Conference on Environment and Development for the World Bank', Journal of Environment and Development, 2 (1993), 67-79.

${ }^{24}$ Erik Gartzke, Charles Boehmer, Timothy Nordstrom and J. Joseph Hewitt, 'disaggregating International Organizations in Time and Space' (paper presented at the Annual Meeting of the American Political Science Organization, Philadelphia, 2006), p. 6.

${ }^{25}$ Charles Boehmer, Erik Gartzke and Timothy Nordstrom, 'Do Intergovernmental Organizations Promote Peace', World Politics, 57 (2004), 1-38, p. 37.

${ }^{26}$ Boehmer, Gartzke and Nordstrom, 'Do Intergovernmental Organizations Promote Peace', p. 37. 
countries to enhance their environmental performance. Hence, I expect that more institutionalized IGOs possess the institutional requirements to influence environmental quality in developing countries, whereas the influence of minimally institutionalized IGOs should not be so pronounced.

HYPOTHESIS 2: The effect on developing countries' environmental quality is greater for more institutionalized IGOs than for minimally institutionalized ones.

\section{Domestic Factors}

In addition to a country being influenced by its degree of international integration, there are important domestic factors that shape its environmental performance. The literature puts special emphasis on a country's income and its political system. Consequently, I will discuss these two factors in the following paragraphs and adapt the argument to the specific context of developing countries.

Income. Many empirical studies find an inverted $\mathrm{U}$-shaped relationship between gross domestic product (GDP) per capita and several indicators of environmental pollution, labelling this the Environmental Kuznets Curve (EKC). ${ }^{27}$ The logic underlying the EKC is that, in the course of a country's economic development, rising national income increases the scale of economic activity, which - all else being equal - leads to rising pollution levels (scale effect). However, after a certain threshold of national income has been reached, pollution is supposed to decline: first, the composition of the economy is likely to change from manufacturing to service industries (composition effect); second, technological progress tends to reduce pollution (technology effect). In addition, during the early stages of economic development, environmental quality is usually considered a luxury good ${ }^{28}$ and since states only have limited resources available, environmental quality usually ranks far behind the demand for better economic conditions. However, once people attain a certain standard of living, environmental quality turns into a normal public good and citizens demand that their government take action to reduce or avoid pollution, for example, by enacting appropriate environmental regulations. ${ }^{29}$

${ }^{27}$ Gene M. Grossman and Alan B. Krueger, 'Economic Growth and the Environment', Quarterly Journal of Economics, 110 (1995), 353-77; Thomas M. Selden and Daqing Song, 'Environmental Quality and Development: Is There a Kuznets Curve for Air Pollution Emissions?' Journal of Environmental Economics and Management, 27 (1994), 147-62; Nemat Shafik and Sushenjit Bandyopadhyay, 'Economic Growth and Environmental Quality' (Working Paper: World Development Report, 1992), 1-55; Hemamala Hettige, Muthukumara Mani and David Wheeler, 'Indutrial Pollution in Economic Development: Kuznets Revisited', Journal of Development Economics, 62 (2000), 445-76; Dasgupta, Laplante, Wang and Wheeler, 'Confronting the Environmental Kuznets Curve'.

${ }^{28}$ A luxury good is a good for which the demand increases with the income level. This implies that at low-income levels the good is usually demanded in small quantities, if at all, whereas its demand increases with growing income.

${ }^{29}$ Selden and Song, 'Environmental Quality and Development'. It is important to note that there exist several studies that criticize the literature on the EKC (Dasgupta, Laplante, Wang and Wheeler, 'Confronting the Environmental Kuznets Curve'; David I. Stern, 'The Rise and Fall of the Environmental Kuznets Curve', World Development, 32 (2004), 1419-39; Daniel L. Millimet, John A. List and Thanasis Stengos, 'The Environmental Kuznets Curve: Real Progress or Misspecified Models?' Review of Economics and Statistics, 85 (2003), 1038-47; Roger Perman and David I. Stern, 'Evidence from Panel Unit Root and Cointegration Tests that the Environmental Kuznets Curve Does Not Exist', Australian 
Applied to the context of developing countries, the EKC argument implies that most, if not all, of these countries should be situated on the upward sloping part of the curve. This means that these countries are confronted with deteriorating environmental quality when experiencing economic growth, since at their present stage of economic development neither the composition nor the technological effect would outweigh the scale effect. Consequently, we should expect that for developing countries an increase in national income would be associated with a reduction in environmental quality, because these countries have not yet reached the point after which an increase in national income is associated with an increase in environmental quality.

Political system. In addition to the effects of the EKC argument that developing countries will face increasing environmental degradation as they get wealthier, even democratic political structures might not play a positive role in the provision of environmental quality in developing countries.

A number of studies relate democracy or democratic structures to environmental quality. ${ }^{30}$ Most of this literature shows that democracies, in general, tend to be better providers of environmental quality, although the magnitude of the effect seems to vary strongly with the particular indicator used to proxy environmental quality. The general logic underlying most of these studies is that democracies provide more public goods to their citizens than do autocracies because democratic leaders need the support of the majority of their citizenry in order to survive in office. ${ }^{31}$ In this context, the recent literature often relies on Bueno de Mesquita et al.'s selectorate theory to analyse the influence of the political system

(F'note continued)

Journal of Agricultural and Resource Economics, 47 (2003), 325-47; Junyi Shen, 'A Simultaneous Estimation of Environmental Kuznets Curve: Evidence from China', China Economic Review, 17 (2006), 383-94; Florenz Plassmann and Neha Khanna, 'Household Income and Pollution: Implications for the Debate About the Environmental Kuznets Curve', Journal of Environment and Development, 15 (2006), 22-41). The main criticism is that the inverted U-shaped relationship described by the EKC does not reflect the true relationship between environmental quality and national income for two reasons. First, it does not capture all of the factors important for the relationship between income and pollution. Second, most statistical models are not correctly specified. In contrast to the findings of the EKC, the critics argue that the relationship between income and pollution should be either monotonically increasing for all levels of national income or, in the most optimistic setting, pollution might level off for high income countries but not decline. It is important to note that this criticism does not cut against the predictions of my arguments, since they would only reinforce the positive relationship between national income and pollution, which is proposed in this article.

${ }^{30}$ Mariano Torras and James K. Boyce, 'Income, Inequality, and Pollution: A Reassessment of the Environmental Kuznets Curve', Ecological Economics, 25 (1998), 147-60; Neumayer, 'Do Democracies Exhibit Stronger International Environmental Commitment?'; Deacon, 'Dictatorship, Democracy, and the Provision of Public Goods'; Per G. Fredriksson, Eric Neumayer, Richard Damania and Scott Gates, 'Environmentalism, Democracy, and Pollution Control', Journal of Environmental Economics and Management, 49 (2005), 343-65; Ward, 'Liberal Democracy and Sustainability'; Thomas Bernauer and Vally Koubi, 'Effects of Political Institutions on Air Quality', Ecological Economics, 68 (2009), $1355-65$.

31 Bruce Bueno de Mesquita, Alastair Smith, Randolph M. Siverson and James D. Morrow, The Logic of Political Survival (Cambridge, Mass.: MIT Press, 2003); Robert T. Deacon, 'The Political Economy of Environment-Development Relationships: A Preliminary Framework' (Working Paper, University of California, Santa Barbara, 1999), 1-33; Deacon, 'Dictatorship, Democracy, and the Provision of Public Goods'; Manus I. Midlarsky, 'Democracy and the Environment: An Empirical Assessment', Journal of Peace Research, 35 (1998), 341-61; Martin C. McGuire and Mancur Olson, 'The Economics of Autocracy and Majority Rule: The Invisible Hand and the Use of Force', Journal of Economic Literature, 34 (1996), 72-96; Mancur Olson, 'Dictatorship, Democracy, and Development', American Political Science Review, 87 (1993), 567-76. 
on the provision of public goods. ${ }^{32}$ Bueno de Mesquita et al. define the selectorate as the group that is eligible to select the leader of a country. The winning coalition is then defined as the subgroup of the selectorate whose support is necessary for the leader to gain or stay in power. In a democracy with a majoritarian electoral system, the winning coalition would be about half of the selectorate, whereas in an autocracy this would be a small elite group usually consisting of the military or party elites. Applying Bueno de Mesquita et al.'s terminology, we can deduce that leaders in autocracies need to satisfy a smaller winning coalition in order to stay in power compared with leaders in democratic countries. ${ }^{33}$ Since leaders have only limited resources at their disposal to attain political support, it follows that autocratic leaders can concentrate these resources on their small winning coalition, whereas leaders in democracies need to disperse their resources to a larger group. To maximize political support given their resources, it is more efficient for democratic leaders to provide public goods than to buy off their winning coalition with targeted private goods. Consequently, democratic leaders should provide more public goods to ensure the support of a larger group, whereas in autocracies leaders should mostly rely on private goods targeted to their small winning coalition.

In contrast to Bueno de Mesquita et al.'s reasoning, it can be argued that autocracies might supply more public goods as their leaders usually have a longer planning horizon. ${ }^{34}$ As most environmental problems develop slowly and often only become apparent in the distant future, democratic leaders, who may be seen as being more myopic due to more frequent elections, might not be interested in facing the short-term costs of providing long-term environmental quality ${ }^{35}$ In addition, some studies claim that in mature democracies public goods are underprovided, because special interest groups have gained a disproportionate influence on the government. Therefore, they say, democratic governments often provide private goods to these interest groups instead of providing public goods to the whole population. ${ }^{36}$

The crucial assumption if democracy is to have a positive effect on environmental quality is that the median voter demands that the government provide this public good. However, the particular nature of environmental quality as a luxury good implies that environmental quality is demanded very little or not at all at low-income levels, demand rising as income increases. ${ }^{37}$ People in developing countries might, therefore, not demand that their governments take action in order to enhance environmental quality. As Neumayer notes: 'This need not imply that poor countries care less about the environment per se. Rather, because of their poverty, they might prioritize issues other than the environment ${ }^{38}$ This point is important since I do not argue that people in developing countries do not care about

${ }^{32}$ Bernauer and Koubi, 'Effects of Political Institutions on Air Quality'; Alastair Smith, 'Pernicious Foreign Aid? A Political Economy of Political Institutions and the Effect of Foreign Aid', in International Political Economy Society Inaugural Conference, Princeton, 2006); Bueno de Mesquita et al., The Logic of Political Survival.

${ }^{33}$ Bueno de Mesquita et al., The Logic of Political Survival.

34 As Bueno de Mesquita et al. (The Logic of Political Survival, p. 294) note: once autocratic leaders have survived the first year in office, they usually stay in office for a long period.

${ }^{35}$ Roger Congleton, 'Political Institutions and Pollution Control', Review of Economics and Statistics, 74 (1992), 412-21; Midlarsky, 'Democracy and the Environment'.

${ }^{36}$ Midlarsky, 'Democracy and the Environment'; Mancur Olson, The Rise and Decline of Nations (New Haven, Conn.: Yale University Press, 1982).

37 Ronald Rogowski, 'International Capital Mobility and National Policy Divergence', in Miles Kahler and David A. Lake, eds, Governance in a Global Economy: Political Authority in Transition (Princeton, N.J.: Princeton University Press, 2003), pp. 355-74.

${ }^{38}$ Neumayer, 'Do Democracies Exhibit Stronger International Environmental Commitment?', p. 150. 
pollution. The argument states only that people in developing countries prioritize issues such as economic growth, education or health care over environmental quality. This in turn implies that democratic developing countries that have only limited resources at their disposal might not have strong incentives to invest these resources in the provision of environmental quality.

Consequently, I argue that the political system should not have an independent effect on the environmental performance of developing countries. Or, put differently, if there is no (or very little) public demand pressuring a government to increase environmental quality, democratic governments do not have enough electoral incentives to spend scarce resources on improving their environmental performance. Hence, democratic developing countries per se should not be characterized by higher environmental quality relative to their autocratic counterparts.

In summary, this article postulates that membership in international organizations can improve the environmental performance of developing countries by linking different issues, by promoting the general idea of environmental sustainability, and by providing a channel through which these countries may receive technology and resources necessary to reduce pollution. Furthermore, the theoretical arguments suggest that an increase in a country's income should be associated with a decrease in its environmental performance, while the political system should not play a decisive role in the provision of environmental quality in developing countries.

\section{EMPIRICAL ANALYSIS}

I use time-series cross-country (TSCS) analysis covering the period 1970-2000 to test my hypotheses. Based on the theoretical arguments, the sample consists of all developing countries in the world. Each year the World Bank publishes a classification of countries into low-income, lower-middle income, higher-middle income and high-income groups. ${ }^{39}$ Following this classification, I include in my sample all countries that are not characterized as 'high-income'. Since the classification threshold varies each year, the highest threshold, which is the one in the year 2000, was chosen. Hence, the 114 countries with a Gross National Income (GNI) per capita level of less than US\$ 9,266 were included in the sample. However, in order to test the robustness of my results, all the statistical models were re-estimated using only the samples that include all the countries up to the lower-middle income level (US\$ 2,995) and up to the low-income level (US\$ 755) classification thresholds, respectively. The results were not sensitive to sample size. ${ }^{40}$

\section{Variables}

The motivation behind this article is to identify whether membership in IGOs can help developing countries curtail their environmental pollution. Although environmental regulation is often a necessary condition for improved environmental outcomes, several reasons have led me to focus exclusively on environmental quality measures. First, in contrast to domestic environmental policy outputs, environmental quality measures are in most cases easily comparable across countries, especially in the case of developing countries. Second, alongside country fixed effects, the empirical design controls for

39 See: http://data.worldbank.org/about/country-classifications.

40 The World Bank calculates annual gross national income (GNI) per capita levels using its Atlas method to diminish the impact that exchange rate fluctuations have on the cross-country comparison of national incomes. 
various factors such as economic growth and population structure that could potentially compromise governments' ability to affect environmental quality. Third, it is usually the case that citizens care more about whether pollution is reduced than whether their government has enacted certain environmental regulations; therefore, environmental quality measures should be at the heart of this study.

In the literature, many different measures of environmental quality have been employed such as indicators of air quality, ${ }^{41}$ water quality ${ }^{42}$ or indices that combine several measures of environmental quality such as the environmental sustainability index or the genuine savings index. ${ }^{43}$ Unfortunately, the paucity of data that exists in time-series crosssection format limits the choice to sulphur dioxide $\left(\mathrm{SO}_{2}\right)$ and carbon dioxide $\left(\mathrm{CO}_{2}\right)$ emissions. ${ }^{44}$ The two indicators are measured in levels instead of growth rates for two reasons. First, I consider levels as more appropriate, since all my arguments refer to the quality of the environment and not to changes in environmental performance. And, second, changes could be misleading in the sense that the growth rate of pollution may be high, implying bad environmental performance, whereas the overall state of the environment is still good; or growth rates may be low while the state of the environment is quite bad.

Both indicators proxy for important aspects of environmental quality: $\mathrm{SO}_{2}$ is a primary contributor to acid rain and detrimental to human health and the well-being of the ecosystem. It mostly arises from burning fossil fuels such as coal or oil and is primarily emitted by power plants, petroleum refineries, metal processing facilities, locomotives and large ships. The data on $\mathrm{SO}_{2}$ emissions are taken from Stern. ${ }^{45} \mathrm{CO}_{2}$ is largely a by-product of energy production and use and is mainly released during the combustion of fossil fuels and cement manufacturing. ${ }^{46} \mathrm{CO}_{2}$ emissions are the primary contributor to global warming and climate change since they account for the majority of greenhouse gases. ${ }^{47}$ The data on $\mathrm{CO}_{2}$ emissions come from the World Bank's Development Indicators. ${ }^{48}$ Both $\mathrm{SO}_{2}$ and $\mathrm{CO}_{2}$ emissions are measured in thousand metric tons per capita in order to control for

\footnotetext{
41 Grossman and Krueger, 'Economic Growth and the Environment'.

${ }^{42}$ Hilary Sigman, 'International Spillovers and Water Quality in Rivers: Do Countries Free Ride?' American Economic Review, 92 (2002), 1152-59.

43 Indra De Soysa and Eric Neumayer, 'False Prophet, or Genuine Savior? Assessing the Effects of Economic Openness on Sustainable Development, 1980-99', International Organization, 59 (2005), 731-72.
}

44 Data on water quality, on biological oxygen demand in particular, also exist in time-series format. However, availability of the data limits the time frame to 1980-2000, which makes a comparison with the results of this analysis somewhat difficult. The main results, however, do not change when using Biological Oxygen Demand instead of $\mathrm{SO}_{2}$ or $\mathrm{CO}_{2}$ emissions and are available upon request. Furthermore, although there are environmental performance indices, their use for time-series crosssection analysis is limited. For example, the composition of the environmental sustainability index changes from year to year, rendering it non-valuable for time-series analysis. Moreover, the concept of genuine savings intends to measure the true rate of savings in an economy after taking into account investments in human capital, depletion of natural resources and damage caused by pollution. Although it can be seen as a measure of weak sustainability (De Soysa and Neumayer, 'False Prophet, or Genuine Savior?'), its environmental component is very small, implying that genuine savings are not a valuable indicator of environmental performance per se.

45 David I. Stern, 'Global Sulfur Emissions from 1850 to 2000', Chemosphere, 58 (2005), 163-75.

46 World Bank, 'World Development Indicators', http://go.worldbank.org/U0FSM7AQ40, 2006).

47 World Bank, 'World Development Indicators'.

48 World Bank, 'World Development Indicators'. 
population size. I use the natural $\log$ of both variables because of their long right-tail distribution.

Theory suggests that developing countries that are members of more IGOs should emit less $\mathrm{SO}_{2}$ and $\mathrm{CO}_{2}$. However, the different natures of the two pollutants suggest that the effect could be stronger in the case of $\mathrm{SO}_{2}$ and less pronounced in the case of $\mathrm{CO}_{2}$. This is because $\mathrm{SO}_{2}$, compared with $\mathrm{CO}_{2}$, is a local air pollutant whose adverse effects on the environment and human health are felt locally. In contrast, the harm arising from $\mathrm{CO}_{2}$ pollution is of a global nature, implying that governments need to co-ordinate in order to combat the effects of $\mathrm{CO}_{2}$ emissions, which opens the possibility for free-riding behaviour. Furthermore, the effects of $\mathrm{CO}_{2}$ emissions, such as climate change, are long term in nature, whereas $\mathrm{SO}_{2}$ emissions have more short-term effects, such as acid rain. This might give governments an additional incentive to prioritize the abatement of $\mathrm{SO}_{2}$ over $\mathrm{CO}_{2}$ emissions. Hence, we might see a difference in the magnitude of the negative effects of IGO with the effect being bigger for $\mathrm{SO}_{2}$.

The main independent variables of my analysis are a country's membership in intergovernmental organizations, its income and its political system. The first independent variable is operationalized as the yearly cumulative count of each country's IGO memberships. The data come from the Correlates of War Project (COW). ${ }^{49}$ The use of this cumulative measure is appropriate as this acknowledges that being a member of a certain number of IGOs limits a country's options for further membership, whereas the number of new memberships per annum does not do so.

To evaluate the argument that more institutionalized IGOs may be more effective in influencing developing countries' environmental performance than IGOs that only exist on paper, I rely on data from Boehmer et al. ${ }^{50}$ They code three degrees of institutionalization: minimally, moderately and highly institutionalized IGOs. ${ }^{51}$ Minimally institutionalized IGOs are organizations that 'lack any bureaucratic, executive, or judicial organs that possess any formalized power, ${ }^{52}$ Medium institutionalization refers to organizations to which 'member states relinquish minimal amounts of their sovereignty to support IGO projects and missions ${ }^{53}$, and highly institutionalized IGOs are organizations that 'possess clear mechanisms for coercing or influencing state behavior, ${ }^{54}$

The political system of a country is operationalized using the combined Polity IV score ranging from 1 - most autocratic - to 21 - most democratic. ${ }^{55}$ Polity IV captures the competitiveness of political participation, the guarantee of openness and competitiveness of executive recruitment, and the existence of institutionalized constraints on the exercise of executive power. Since Polity IV has been criticized with regard to its aggregation procedure ${ }^{56}$ I use two additional measures of democracy for robustness checks. First,

${ }^{49}$ Pevehouse, Nordstrom and Warnke, 'Intergovernmental Organizations, 1815-2000'.

${ }^{50}$ Boehmer, Gartzke and Nordstrom, 'Do Intergovernmental Organizations Promote Peace?'

${ }^{51}$ Boehmer, Gartzke and Nordstrom, 'Do Intergovernmental Organizations Promote Peace?'

52 Boehmer, Gartzke and Nordstrom, 'Do Intergovernmental Organizations Promote Peace?' p. 37.

${ }^{53}$ Boehmer, Gartzke and Nordstrom, 'Do Intergovernmental Organizations Promote Peace?' p. 37.

${ }_{55}^{54}$ Boehmer, Gartzke and Nordstrom, 'Do Intergovernmental Organizations Promote Peace?' p. 38.

55 Monty G. Marshall and Keith Jaggers, 'Polity IV Project: Political Regime Characteristics and Transitions, 1800-2002'. The original Polity IV score ranges from -10 (most autocratic) to +10 (most democratic). To facilitate interpretation, the variable is transformed to be positive throughout its complete range. This innocuous change does not affect the results.

56 Gerardo L. Munck and Jay Verkuilen, 'Conceptualizing and Measuring Democracy', Comparative Political Studies, 35 (2002), 5-34. 
I rely on the dichotomous index of democracy developed by Alvarez et al. (ACLP index) ${ }^{57}$ and, second, I use Bueno de Mesquita's measure capturing the size of the winning coalition relative to the size of the selectorate. ${ }^{58}$

To account for the effect of national income on pollution, the log of GDP per capita is included in the model. Although the logic of the environmental Kuznets curve suggests that both GDP per capita and its square term should be included in the regression model, doing so results in statistically insignificant estimated coefficients for both variables. ${ }^{59}$ This is due to the fact that the analysis is restricted to developing countries. Here we should observe income negatively impacting on environmental performance. ${ }^{60}$ Therefore, using a quadratic specification does not capture the theoretically expected relationship. The data on national income come from Gleditsch, which is an updated version of the Penn World Tables. ${ }^{61}$

A number of control variables are also included in the statistical model. I control for the fact that a growing economy is often associated with environmental degradation. Since a larger population usually consumes more natural resources and thereby produces greater environmental degradation, population density is also included. ${ }^{62}$

Several existing studies have examined the economic facets of globalization and their influence on environmental quality. To be able to separate the impact of international political integration from the economic aspects of international integration, I also include a country's trade openness and its foreign direct investment (FDI) inflows. The literature on economic globalization and provision of public goods contrasts arguments on general welfare enhancing gains with arguments on regulatory competition. ${ }^{63}$ According to the first argument, stronger economic integration should have, on average, a positive effect on environmental quality because of the welfare enhancing gains of globalization. In particular, it is argued that increasing economic integration allows countries to specialize in industries in which they have a comparative advantage, making for a more efficient allocation of resources and higher productivity. As a result, a country's national income is supposed to increase, which then leads to higher public goods provision. ${ }^{64}$ According to the second argument, increasing economic interdependence leads to strong regulatory competition between countries. ${ }^{65}$ In order to increase their competitiveness and attract foreign capital, countries are pushed towards less stringent regulations, which can lead to

${ }^{57}$ Michael Alvarez, José Antonio Cheibub, Fernando Limongi and Adam Przeworski, 'Classifying Political Regimes', Studies in Comparative International Development, 31 (1996), 1-37.

${ }_{58}$ Bueno de Mesquita, Smith, Siverson and Morrow, The Logic of Political Survival.

59 Results are available from the author upon request.

${ }^{60}$ Estimating a quadratic model of GDP per capita on environmental performance using all countries' yields to a turning point of $\$ 23,192$ in the case of $\mathrm{SO}_{2}$ and to a turning point that is out of sample in the case of $\mathrm{CO}_{2}$.

${ }^{61}$ Kristian Skrede Gleditsch, 'Expanded Trade and GDP Data', Journal of Conflict Resolution, 46 (2002), 712-24.

${ }^{62}$ COW Correlates of War, 'Data Set of National Military Capabilities. Version 3.02', 2008; J. David Singer, Stuart Bremer and John Stuckey, 'Capability Distribution, Uncertainty, and Major Power War, 1820-1965', in Bruce Russett, ed., Peace, War, and Numbers (Beverly Hills, Calif.: Sage, 1972), 19-48.

${ }^{63}$ Frankel and Rose, 'Is Trade Good or Bad for the Environment?'

${ }^{64}$ Frankel and Rose, 'Is Trade Good or Bad for the Environment?'; Antweiler, Copeland and Taylor, 'Is Free Trade Good for the Environment?'

${ }^{65}$ L. Zarsky, 'Havens, Halos and Spaghetti: Untangling the Evidence about Foreign Direct Investment and the Environment' (OECD Conference on Foreign Direct Investment and the Environment, The Hague, 1999). 
TABLE 1 Descriptive Statistics

\begin{tabular}{lrrrrr}
\hline \hline Variable & Mean & Std. Dev. & Min & Max & Observations \\
\hline $\mathrm{SO}_{2}$ per capita (in metric tons $\left.\times 1,000\right)$ & 0.01 & 0.02 & 0.00 & 0.19 & 2,572 \\
$\mathrm{CO}_{2}$ per capita & 1.83 & 2.74 & 0.01 & 24.19 & 2,663 \\
IGO membership & 49.19 & 16.27 & 1 & 96 & 2,663 \\
GDP per capita (US\$) & $3,402.68$ & $2,717.11$ & 281.26 & $16,667.88$ & 2,663 \\
Polity IV & 9.89 & 6.94 & 1 & 21 & 2,663 \\
$\mathrm{BDM}$ & 0.51 & 0.29 & 0 & 1 & 2,663 \\
In Trade Openness & 15.99 & 0.84 & -19.03 & -12.56 & 2,663 \\
FDI inflows in \% of GDP & 1.53 & 5.19 & -82.81 & 145.13 & 2,663 \\
Population density & 55.23 & 92.57 & 0.01 & 844.18 & 2,663 \\
Growth & 1.01 & 0.33 & 0.54 & 17.98 & 2,663 \\
\hline \hline
\end{tabular}

Note: Negative values for FDI net inflows per capita imply that more capital is going out of the country than coming into the country.

either a regulatory chill or even to a race to the bottom that would undermine the provision of public goods such as environmental quality and social welfare benefits. Which of the two effects actually prevails is mainly an empirical question. ${ }^{66}$ Trade openness is measured by the yearly ratio of the sum of exports and imports to GDP. ${ }^{67}$ FDI inflows are measured in percent of GDP and the data are taken from the World Bank Development Indicators.

Finally, a time trend is added to the model in order to control for events such as technology improvements over time. Table 1 displays descriptive statistics of the variables used in the regression models.

\section{Empirical Results}

To test the implications of my arguments empirically I use a fixed-effects estimation procedure with panel-corrected standard errors (PCSE) and a Prais-Winsten specification to control for autocorrelation. Since IGO membership effects may need some time to trickle through, all of the independent and control variables enter into the model with a one-year time lag. ${ }^{68}$

Table 2 shows the results of testing Hypothesis 1, anticipating a positive relationship between IGO membership and environmental performance. As expected, membership in international organizations has a positive influence on the environmental performance of developing countries as measured by either of the two indicators. ${ }^{69}$ Interestingly, the results do not show a distinct difference between the coefficient of IGO membership in the models for $\mathrm{SO}_{2}$ and $\mathrm{CO}_{2}$, although $\mathrm{CO}_{2}$ emissions pose a more global and long-term threat, in contrast to $\mathrm{SO}_{2}$ emissions, whose adverse effects are of a more local and short-term nature.

66 Jeffrey A. Frankel, 'The Environment and Globalization' (NBER Working Paper, 2003), 1-40.

${ }^{67}$ Gleditsch, 'Expanded Trade and GDP Data'.

${ }^{68}$ However, results do not change if contemporaneous variables are used. In contrast, some results are even more significant. Consequently, using a one-year time lag of all of the independent and control variables seems to be a more conservative approach. Results using contemporaneous variables are available upon request.

${ }^{69}$ Since the dependent variable is pollution emissions, a negative coefficient sign implies a reduction in emissions and therefore an increase in environmental quality. 
TABLE $2 \quad I G O$ Membership and Environmental Quality

\begin{tabular}{|c|c|c|c|c|}
\hline Variable & $\begin{array}{c}(1) \\
\ln \mathrm{SO}_{2} \mathrm{pc}\end{array}$ & $\begin{array}{c}(2) \\
\ln \mathrm{CO}_{2} \mathrm{pc}\end{array}$ & $\begin{array}{c}(1) \\
\ln \mathrm{SO}_{2} \mathrm{pc}\end{array}$ & $\begin{array}{c}(2) \\
\ln \mathrm{CO}_{2} \mathrm{pc}\end{array}$ \\
\hline IGO membership & $\begin{array}{c}-0.01 * * * \\
(0.00)\end{array}$ & $\begin{array}{c}-0.01 * * * \\
(0.00)\end{array}$ & & \\
\hline Minimal & & & $\begin{array}{c}0.00 \\
(0.00)\end{array}$ & $\begin{array}{c}0.00 \\
(0.00)\end{array}$ \\
\hline Structured & & & $\begin{array}{c}-0.02 \\
(0.01)\end{array}$ & $\begin{array}{c}-0.03 * * * \\
(0.01)\end{array}$ \\
\hline Interventionist & & & $\begin{array}{c}-0.02 * \\
(0.01)\end{array}$ & $\begin{array}{r}-0.00 \\
(0.00)\end{array}$ \\
\hline $\ln$ GDP pc & $\begin{array}{l}0.42 * * * \\
(0.05)\end{array}$ & $\begin{array}{l}0.53^{* * *} \\
(0.05)\end{array}$ & $\begin{array}{l}0.43^{* * *} \\
(0.05)\end{array}$ & $\begin{array}{l}0.54 * * * \\
(0.05)\end{array}$ \\
\hline Polity & $\begin{array}{c}-0.00 \\
(0.00)\end{array}$ & $\begin{array}{c}-0.00 \\
(0.00)\end{array}$ & $\begin{array}{c}-0.00 \\
(0.00)\end{array}$ & $\begin{array}{c}-0.00 \\
(0.00)\end{array}$ \\
\hline In trade openness & $\begin{array}{c}0.04 \\
(0.03)\end{array}$ & $\begin{array}{l}0.10^{* * *} \\
(0.02)\end{array}$ & $\begin{array}{c}0.03 \\
(0.03)\end{array}$ & $\begin{array}{l}0.10^{* * *} \\
(0.02)\end{array}$ \\
\hline FDI & $\begin{array}{c}0.00 \\
(0.00)\end{array}$ & $\begin{array}{c}-0.00 \\
(0.00)\end{array}$ & $\begin{array}{c}-0.00 \\
(0.00)\end{array}$ & $\begin{array}{c}-0.00 \\
(0.00)\end{array}$ \\
\hline Population density & $\begin{array}{r}-0.00 \\
(0.00)\end{array}$ & $\begin{array}{l}0.00 * * * \\
(0.00)\end{array}$ & $\begin{array}{r}-0.00 \\
(0.00)\end{array}$ & $\begin{array}{l}0.00^{* * *} \\
(0.00)\end{array}$ \\
\hline ln growth & $\begin{array}{c}-0.01 \\
(0.04)\end{array}$ & $\begin{array}{c}-0.00 \\
(0.04)\end{array}$ & $\begin{array}{c}-0.01 \\
(0.04)\end{array}$ & $\begin{array}{c}-0.01 \\
(0.04)\end{array}$ \\
\hline Time trend & $\begin{array}{c}0.00 \\
(0.01)\end{array}$ & $\begin{array}{l}0.01 * * * \\
(0.00)\end{array}$ & $\begin{array}{c}-0.01 * * * \\
(0.01)\end{array}$ & $\begin{array}{c}0.00 \\
(0.00)\end{array}$ \\
\hline Constant & $\begin{array}{c}0.00 \\
(0.00)\end{array}$ & $\begin{array}{c}-6.13^{* * *} \\
(0.55)\end{array}$ & $\begin{array}{c}-15.89^{* * * *} \\
(0.60)\end{array}$ & $\begin{array}{c}-6.28^{* * *} \\
(0.55)\end{array}$ \\
\hline rho & 0.77 & 0.72 & 0.77 & 0.71 \\
\hline Observations & 2,572 & 2,663 & 2,572 & 2,663 \\
\hline Number of countries & 106 & 110 & 106 & 110 \\
\hline$R^{2}$ & 0.96 & 0.87 & 0.96 & 0.87 \\
\hline
\end{tabular}

Note: Panel-corrected standard errors in parentheses; ${ }^{* * *} p<0.01,{ }^{*} p<0.05,{ }^{*} p<0.1$. Country effects are not displayed in the regression table.

Columns 3 and 4 in Table 2 show the results when I disaggregate IGO membership according to the degree of institutionalization of the respective organizations. As expected, we see that minimally institutionalized organizations are never associated with a significant reduction in $\mathrm{SO}_{2}$ and $\mathrm{CO}_{2}$ emissions. Interestingly, however, it is not always the most institutionalized IGOs that are significantly associated with better environmental quality. As the results show, highly institutionalized IGOs are the most important organizations only in the case of $\mathrm{SO}_{2}$ emissions. In the case of $\mathrm{CO}_{2}$ emissions, those IGOs with a medium degree of institutionalization seem to be the most influential.

I infer from these findings that some degree of formalization or institutionalization of an organization is needed to affect environmental quality in developing countries. However, it is not necessarily the most institutionalized or powerful organizations, in the sense that they can constrain their member countries the most, that affect environmental quality in developing countries. This could be due to the fact that the main mechanisms behind the influence of IGOs - as proposed in the theoretical part of this article - are technology and knowledge transfer, issue linkage and a broader socialization process towards environmental protection. As long as they fulfil these purposes, organizations 
that possess some degree of institutionalization seem to be associated with better environmental quality in developing countries.

With regard to a country's income, we observe that an increase in GDP per capita is indeed associated with an increase in pollution as predicted by the EKC argument. This confirms the theoretical assertion that the countries in this sample have not yet reached that point on the EKC after which an increase in income would lead to improved environmental quality.

Finally, as argued in the theoretical part, democratic developing countries do not seem to perform better with regard to environmental quality, relative to their autocratic counterparts. The results show no statistically significant effect of the political regime type on either of the two indicators of environmental quality. These results are therefore compatible with the assertion that at the stage of early economic development, environmental quality is perceived as a luxury good, implying that citizens do not demand that their governments spend scarce resources on enhancing environmental quality.

Interestingly, none of the control variables exerts a robust influence. Population density is associated with an increase in $\mathrm{CO}_{2}$ emissions but is not statistically significant for $\mathrm{SO}_{2}$ emissions. Similarly, trade openness turns out to be significant only for $\mathrm{CO}_{2}$ emissions, countries that are more open emitting more $\mathrm{CO}_{2}$. Economic growth and foreign direct with investment, in contrast, are not significantly associated with either $\mathrm{SO}_{2}$ or $\mathrm{CO}_{2}$ emissions.

\section{Further Disaggregation of IGO Membership}

In addition to the degree of institutionalization, the function or purpose of a particular IGO might also be of importance. Although my theoretical arguments potentially apply to all types of IGO, some do seem likely to be more important for certain types than for others. For example, the possibility of issue linkage should be more pronounced in umbrella (multi-purpose) IGOs since they deal with a large variety of issues. Technology transfer, in contrast, should be more likely to occur in more technically oriented IGOs such as agrarian or nuclear IGOs. Furthermore, because of their precise thematic focus, environmental IGOs should clearly be interested in improving environmental quality in developing countries. Hence, defined by purpose, some types of IGOs may have a stronger influence than others.

Ingram et al. code IGOs according to their mandate into general umbrella, political, economic and social organizations. ${ }^{70}$ I extended the time period covered by Ingram et al.'s coding to the year $2000 .^{71}$ The only exception I made to their coding instructions was that I created additional categories for nuclear and agrarian IGOs. Thus, IGOs were categorized as military (for instance, the North Atlantic Treaty Organization (NATO)), umbrella (for example, Association of Southeast Asian Nations (ASEAN), European Union (EU)), economic general (such as the World Trade Organization (WTO) and the International Monetary Fund (IMF)), economic co-operation (for example, the World Bank), economic industry specific (as in Cocoa Producers Alliance), economic standardization (for example, Caribbean Postal Union), social (such as the World Health Organization (WHO), the International Labour Office (ILO), the United Nations Educational, Scientific and Cultural Organization (UNESCO)), environmental (like the Global Environmental Facility (GEF)),

\footnotetext{
70 Ingram, Robinson and Bush, 'The Intergovernmental Network of World Trade'.

71 Ingram, Robinson and Bush, 'The Intergovernmental Network of World Trade'.
} 
nuclear (for example, the International Atomic Energy Agency (IAEA)), and agricultural (for instance, the Food and Agriculture Organization (FAO)) organizations.

Table 3 shows the results using the disaggregated IGO measure instead of the general count variable. Interestingly, only membership in umbrella, economic general and military IGOs exert a significantly negative effect on pollution for both environmental indicators while controlling for membership of other IGO types. Membership in social and nuclear IGOs is of importance only when considering $\mathrm{SO}_{2}$, but it has no effect in the case of $\mathrm{CO}_{2}$ emissions. In contrast, environmental and economic standardization IGOs are associated with lower $\mathrm{CO}_{2}$, but not lower $\mathrm{SO}_{2}$, emissions. Finally, economic co-operation, economic industry specific and agricultural IGOs are never linked to better environmental quality.

In addition to being interesting in its own right, disaggregating IGO membership can provide some intuition concerning the underlying mechanisms whereby IGOs may affect environmental performance in developing countries. The strong effect of umbrella organizations such as the EU or ASEAN, for example, is a first indication that some IGOs seem to be very successful in connecting different issues. Although environmental protection is usually not the main goal of these umbrella organizations, they often concern themselves with environmental issues also Different umbrella organizations such as the EU or ASEAN possess institutionalized committees or departments that deal exclusively with environmental protection. Hence, countries joining these IGOs for economic or political reasons are, as a side effect, also influenced with regard to their environmental quality.

This can be illustrated using the African Union (formerly the Organization of African Unity), an umbrella organization trying to promote greater unity and solidarity between African nations and to foster co-operation in different fields such as economic issues, human rights, etc. Among its institutional bodies, the organization has a Committee on Industry, Science and Technology, Energy, Natural Resources and Environment. ${ }^{72}$ This committee has, for instance, a project on bio, safety jointly undertaken with the German technical co-operation agency (Deutsche Gesellschaft für Technische Zusammenarbeit $\mathrm{GmbH}$ ) to provide the Union's member states with the necessary skills and technical tools to implement the Cartagena Protocol. ${ }^{73}$

The effect of social IGOs in the case of $\mathrm{SO}_{2}$ emissions seems to hint at two different mechanisms. On the one hand, these organizations appear to constitute a good forum for information dissemination, and through the socialization process that takes place at these fora they may also diffuse environmental protection, as proposed in the literature on policy diffusion. ${ }^{74}$ On the other hand, many of these organizations - such as the WHO and ILO - or research related organizations - such as the International Commission for the Scientific Exploration of the Mediterranean Sea - often diffuse knowledge and technology helpful to the environment in general while aiming at improving or preserving human health, labour conditions or biodiversity.

\footnotetext{
72 African Union, 'African Union in a Nutshell', http://au.int/en/about/nutshell (2009); African Union, 'Capacity Building for an Africa-Wide Biosafety System', http://www.africa-union.org/root/au/AUC/ Departments/HRST/biosafety/AU_Biosafety_1b.htm, (2009).

73 The Cartagena Protocol 'seeks to protect biological diversity from the potential risks posed by living modified organisms resulting from modern biotechnology' (ConventiononBiologicalDiversity, 'Cartagena Protocol on Biosafety', http://www.cbd.int/biosafety/background.shtml, 2009).

${ }^{74}$ Cao, 'Networks of Intergovernmental Organizations and Convergence in Domestic Economic Policies'; Beth A. Simmons and Zachary Elkins, 'The Globalization of Liberalization: Policy Diffusion in the International Political Economy', American Journal of Political Science, 98 (2004), 171-88.
} 
TABLE 3 Disaggregating IGO Membership

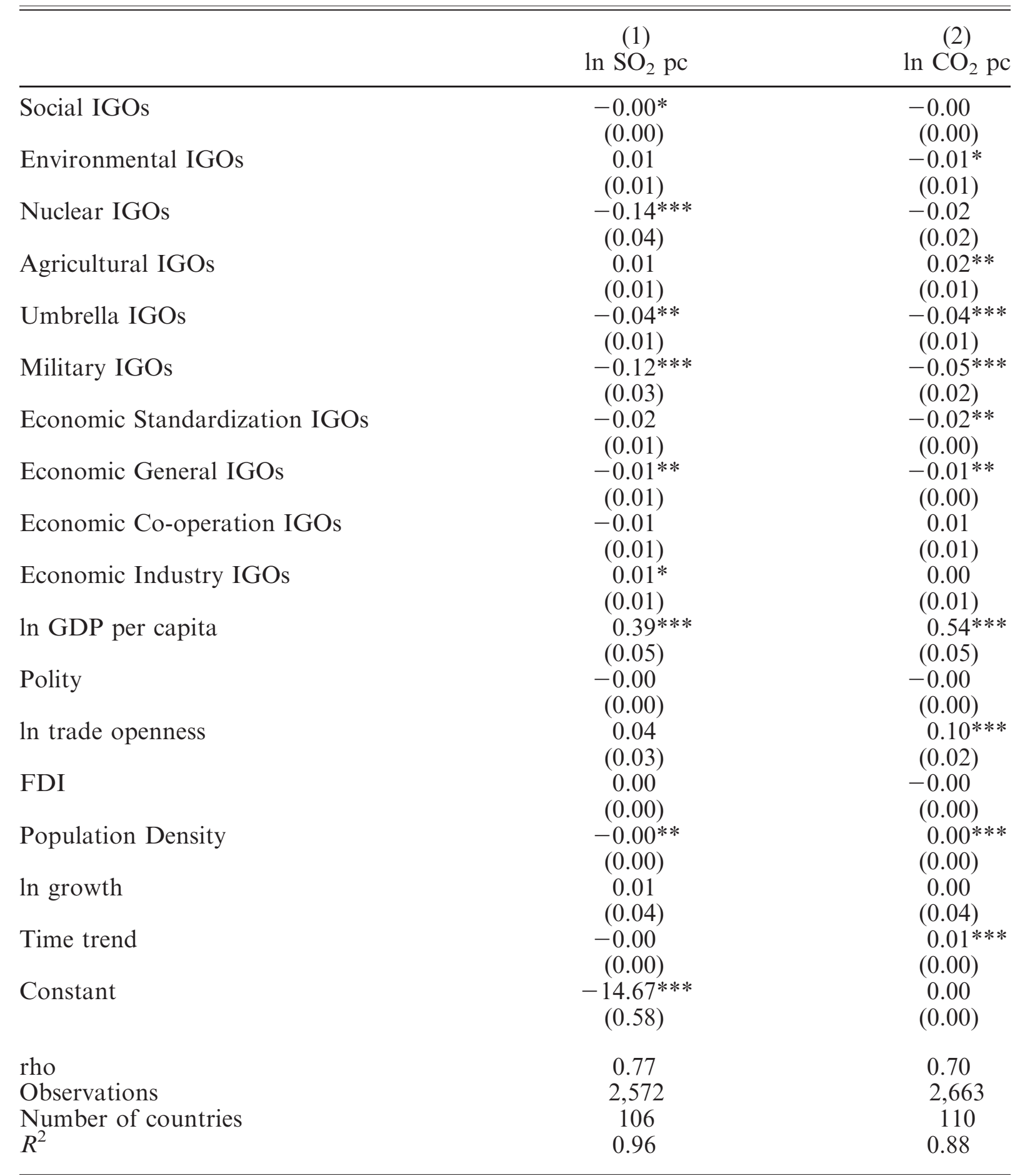

Note: Panel-corrected standard errors in parentheses; $* * * p<0.01, * * p<0.05,{ }^{*} p<0.1$. Country effects are not displayed in the regression table.

Acknowledging the fact that 25 per cent of all diseases worldwide arise because of environmental hazards, the WHO carries out research and gives policy advice on how to deal with various forms of environmental hazards most effectively. ${ }^{75}$ Among other things, the

${ }^{75}$ WHO, 'Public Health and Environment (PHE)', (2009), http://www.who.int/phe/en/. 
WHO offers guidelines on how to dispose of hazardous waste, documents the health risks associated with indoor air pollution, advocates measures to decrease indoor air pollution and monitors the changes in pollution levels in households around the world. These far-reaching measures make the organization an important diffuser of the latest research and knowledge on the impacts of various forms of environmental degradation and on effective countermeasures to tackle the different health problems associated with environmental pollution.

Technology and knowledge transfer as well as capacity building are also sometimes the tasks of nuclear and economic IGOs. For example, UNIDO (the UN Industrial Development Organization), which promotes industrial development mainly by providing technical co-operation, also has a special thematic focus on the environment and energy. In this context, UNIDO provides technical advice on topics such as cleaner production processes, renewable forms of energy and waste recycling. ${ }^{76}$ Similarly, the IAEA supports developing countries with technical co-operation, besides providing information and technology on the safe use of nuclear energy and treatment of nuclear waste. ${ }^{77}$ For example, the IAEA has carried out a project in Cameroon focusing on the use of nuclear techniques in groundwater assessment. ${ }^{78}$

In contrast, the rather small impact of environmental organizations is somewhat surprising, since one would expect that IGOs that are established to deal with environmental issues would have a significant effect on pollution. This finding suggests that, although joining environmental IGOs commits countries to the idea of taking care of their environment, this does not have an impact on the way they act at the national level. ${ }^{79}$

The lack of influence of environmental IGOs does have a methodological advantage as it allows us to address the problem of endogeneity. One potential risk of looking at IGO membership and its influence on environmental quality is that, at least concerning environmental IGOs, countries may 'self-select' into these IGOs. This would imply that only

76 UNIDO, 'Energy and Environment', http://www.unido.org/index.php?id=905 (2009).

77 IAEA, 'Pillars of Nuclear Cooperation', http://www.iaea.org/OurWork/ST/index.html (2009).

78 IAEA, 'National Projects', http://www.iaea.org/OurWork/ST/index.html (2009). Of course, it is also important to note that nuclear IGOs such as IAEA or the Latin American Energy Organization (OLADE) mostly promote the use of nuclear energy production. By relying on nuclear energy production instead of energy production based on fossil fuels, countries that opt for nuclear energy production emit less $\mathrm{SO}_{2}$ and $\mathrm{CO}_{2}$. However, this does not reflect the fact that nuclear energy production produces nuclear waste, which itself constitutes a major environmental problem.

79 It is, however, important to note that this result does not necessarily imply that environmental regimes in general are ineffective. In the present analysis only those regimes that are considered to be an international organization are included, implying that they need to possess an international secretariat. This is only true for a very limited number and for only a very specific set of environmental regimes. For example, the set of environmental IGOs includes organizations such as the International Commission of the Northwest Atlantic Fisheries, now called the Northwest Atlantic Fisheries Organization; the International Whaling Commission; the Joint Anti-Locust and Anti-Aviarian Organization, which aims to control the damage arising from locust and aviarian pests; the International Seabed Authority, which regulates deep seabed mining and aims to protect the marine environment; or Bionet, whose purpose it is to classify natural species. Many of these organizations, however, pursue goals such as combating locust pests in Africa that are not related to any of the measures of environmental quality used in this analysis. Hence, even if these organizations were effective for the purpose for which they were created, they would not affect air quality or greenhouse gas emissions because of their specialization. In contrast, other important environmental regimes such as the Convention on Long-Range Transboundary Air Pollution are not included in this sample because they are not considered to be an international organization. Therefore, the results of this analysis cannot be interpreted as evidence against the effectiveness of environmental regimes in general. 
countries with a very good environmental record would join environmental IGOs because these countries can be sure of meeting the obligations prescribed by the respective organization. Yet, one could also argue that countries with larger environmental problems may be more willing to join environmental organizations, since these organizations could provide laggard countries with technology and know-how. Alternatively, polluting countries may join environmental organizations in order to signal to their citizenry that henceforward they are planning to take the environment more seriously. Since environmental IGOs are - if at all - only vaguely associated with $\mathrm{CO}_{2}$ emissions, we can be rather confident that results are not due to self-selection into the organizations that do have an impact.

To provide further corroboration for the idea that technology and knowledge transfer as well as capacity building are indeed part of the influence of the different types of organizations, I have run the analysis on three different samples: all countries (i.e. including high-income countries), middle-income and low-income countries, and lowincome countries only. If technology transfer is indeed one mechanism through which IGO membership influences the provision of environmental quality, we should observe that the effect of the various IGO memberships is stronger in the developing country sample than in the sample that also includes high-income countries. As the results in Table 4 show, the effect of umbrella, nuclear, military and general economic IGOs is weaker in samples including high-income countries than in the sample with low-income countries only. These findings thus reinforce the conclusion that membership in IGOs can be an opportunity for developing countries to obtain access to advanced technology and knowledge of how to combat environmental degradation.

In addition to disaggregating IGO membership, I checked the robustness of my results using the different variables offered by the Correlates of War project. ${ }^{80}$ The Correlates of War IGO dataset offers three slightly different variables measuring IGO membership. These measures differ according to whether a state has full, associated or observer membership. Up to now I have used the most inclusive (or least 'stringent') variable, the one that includes full, associated and observer membership. However, using either the most narrowly defined variable, which includes full membership only, or the IGO variable that includes both full and associated membership, while excluding observer status, instead of the most inclusive IGO variable, does not alter any of the earlier results. IGO membership, independent of its measurement, is always associated with a reduction in pollution (see columns 1 to 4 in Table 5).

Moreover, although the test statistic for non-stationarity of panel data shows that all independent variables are stationary, each country's IGO membership usually increases over time. Therefore, it could be possible that the effect of IGO membership is merely due to this time trend and is not driven by IGO membership per se. To show that this is not the case, I created a variable that measures the deviation of each country's IGO membership from the average IGO membership per year. Positive deviations thus imply that this country is a member of more IGOs than the average country in this year whereas negative deviations imply that this country is a member of fewer IGOs than the average country. The results, as shown in columns 5 and 6 in Table 5, are the same as in the case of the general IGO variable: countries that are members of more than the average number of IGOs are better stewards of their environment.

\footnotetext{
${ }^{80}$ Pevehouse, Nordstrom and Warnke, 'Intergovernmental Organizations, 1815-2000: A New Correlates of War Data Set. Version 2.1'.
} 


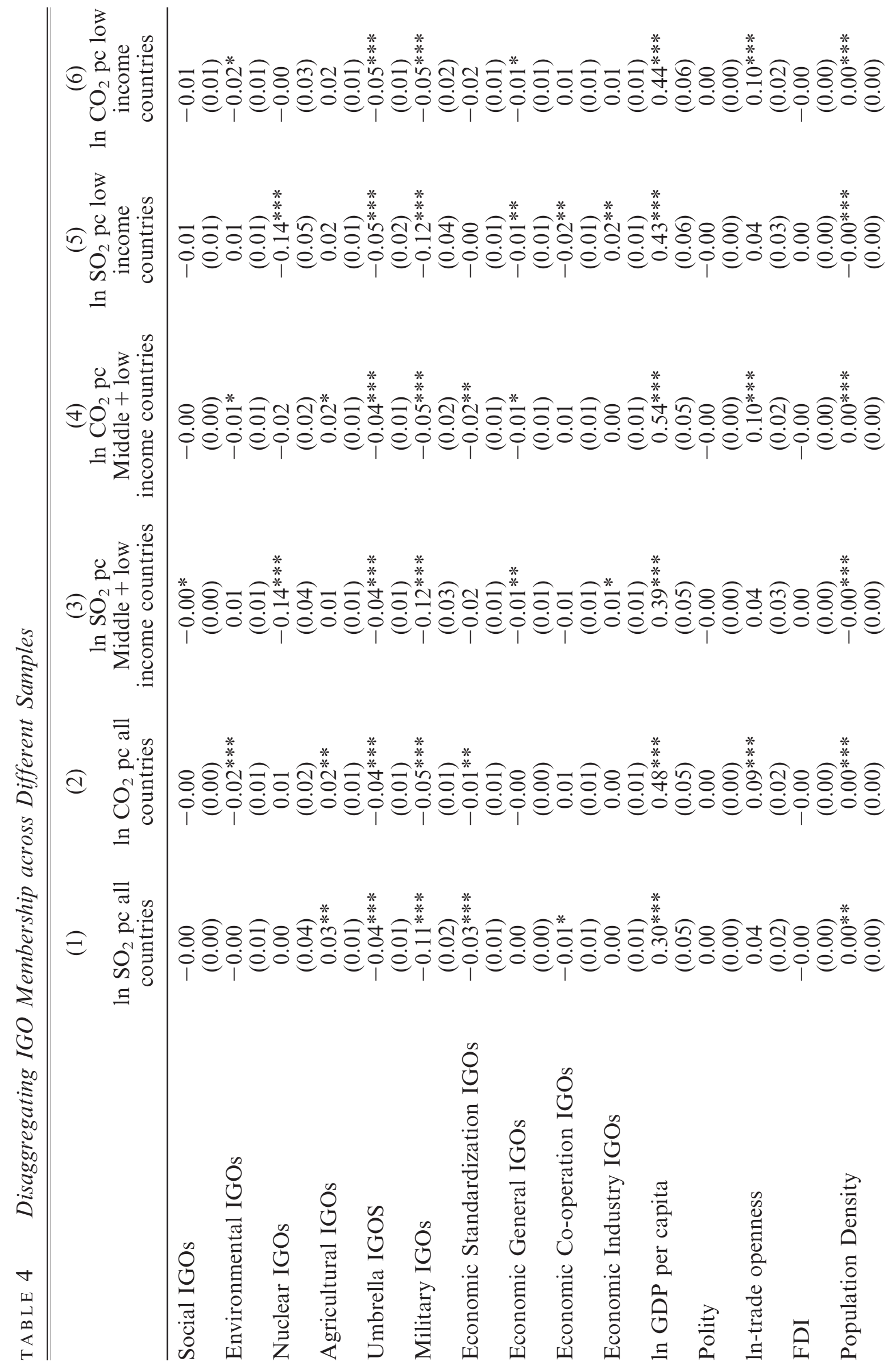




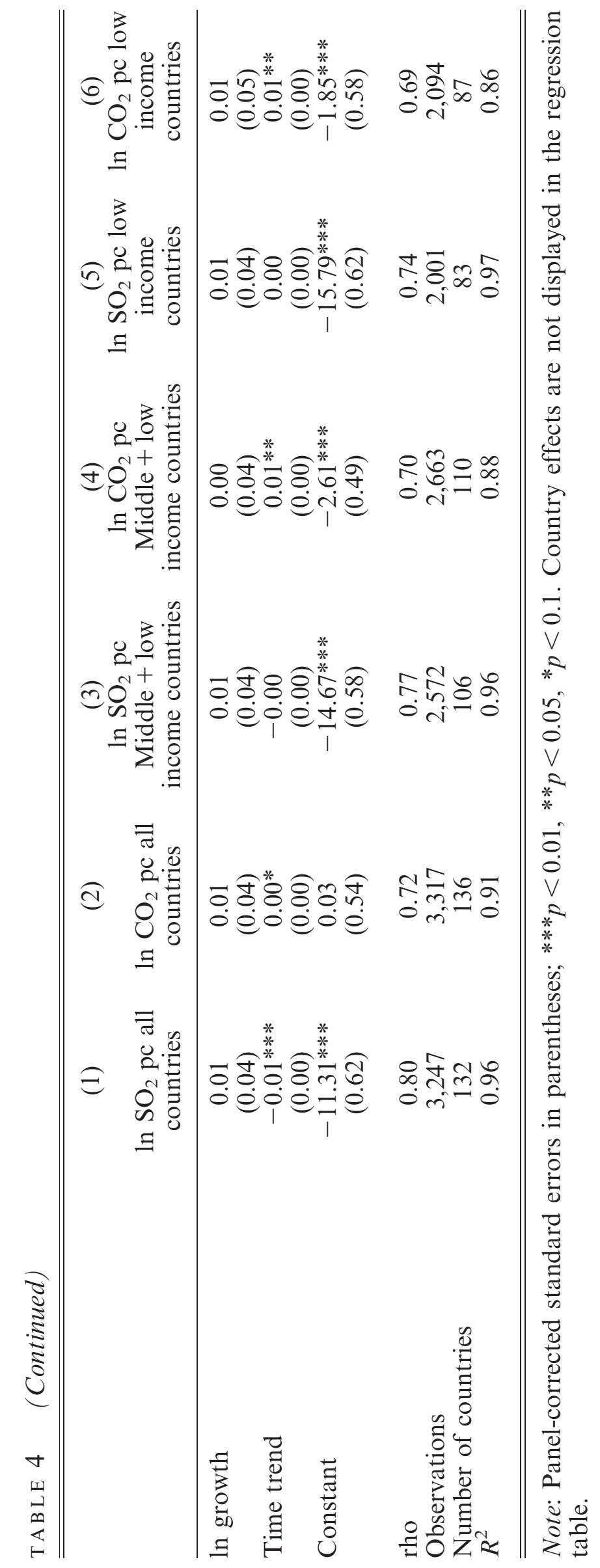




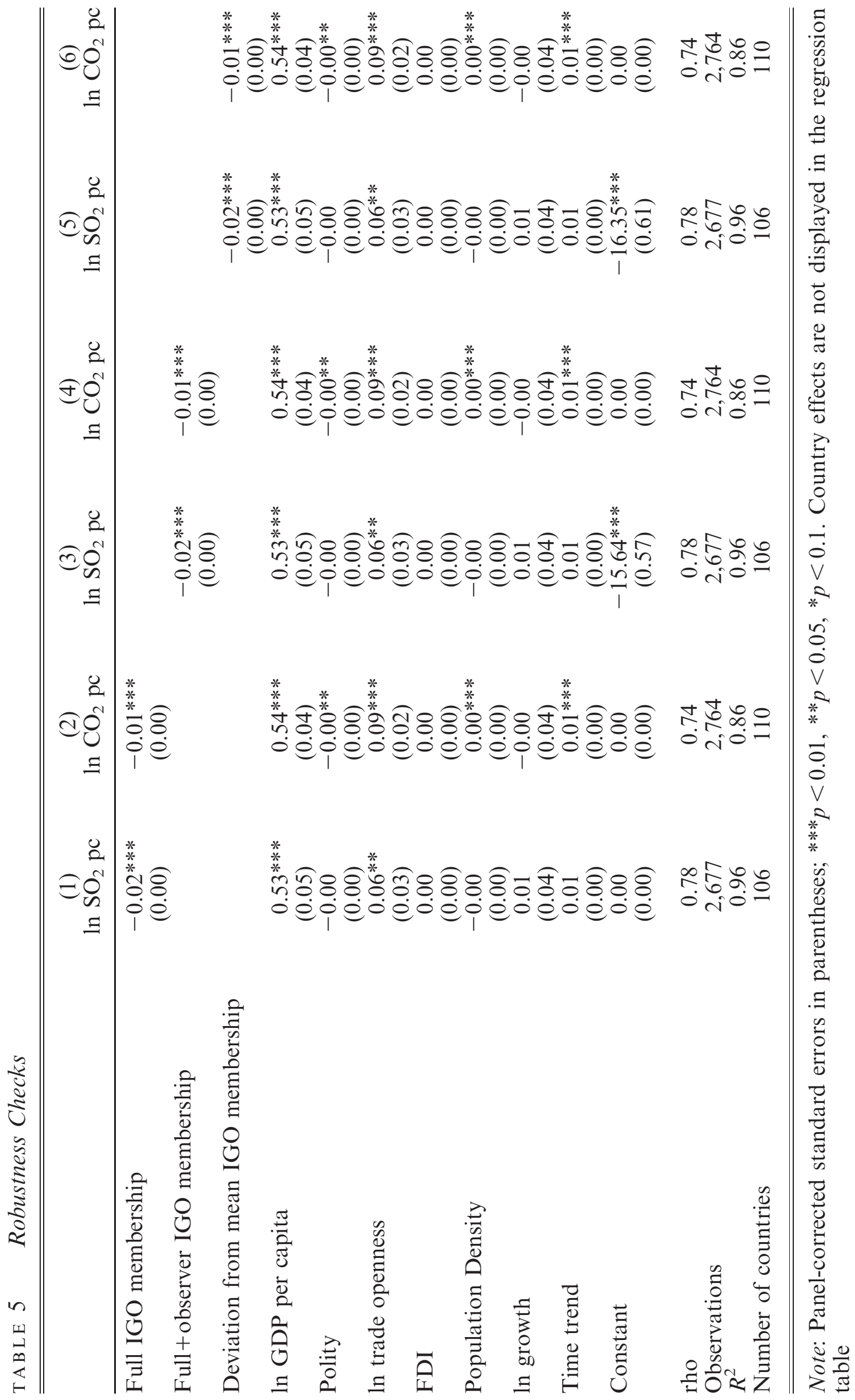


TABLE 6 Robustness Checks

\begin{tabular}{lcccc}
\hline \hline & $(1)$ & $(2)$ & $(3)$ & $(4)$ \\
& $\ln \mathrm{SO}_{2} \mathrm{pc}$ & $\ln \mathrm{CO}_{2} \mathrm{pc}$ & $\ln \mathrm{SO}_{2} \mathrm{pc}$ & $\ln \mathrm{CO}_{2} \mathrm{pc}$ \\
\hline IGO membership & $-0.01^{* * *}$ & $-0.01^{* * *}$ & $-0.01^{* * * *}$ & $-0.01^{* * *}$ \\
& $(0.00)$ & $(0.00)$ & $(0.00)$ & $(0.00)$ \\
ln GDP per capita & $0.41^{* * *}$ & $0.52^{* * *}$ & $0.41^{* * *}$ & $0.52^{* * *}$ \\
& $(0.05)$ & $(0.05)$ & $(0.05)$ & $(0.05)$ \\
ACLP democracy measure & -0.03 & -0.01 & & \\
& $(0.02)$ & $(0.02)$ & & 0.01 \\
BDM democracy measure & & & $(0.03)$ & $(0.04)$ \\
ln trade openness & 0.04 & $0.09^{* * *}$ & 0.04 & $0.09^{* * *}$ \\
& $(0.03)$ & $(0.02)$ & $(0.03)$ & $(0.02)$ \\
FDI & 0.00 & -0.00 & -0.00 & -0.00 \\
Population Density & $(0.00)$ & $(0.00)$ & $(0.00)$ & $(0.00)$ \\
& -0.00 & $0.00^{* * *}$ & -0.00 & $0.00^{* * *}$ \\
ln growth & $(0.00)$ & $(0.00)$ & $(0.00)$ & $(0.00)$ \\
Time trend & -0.01 & -0.00 & -0.01 & -0.00 \\
& $(0.04)$ & $(0.04)$ & $(0.04)$ & $(0.04)$ \\
Constant & 0.00 & $0.01^{* * *}$ & 0.00 & $0.01^{* * *}$ \\
& $(0.00)$ & $(0.00)$ & $(0.00)$ & $(0.00)$ \\
rho & $-15.86^{* * *}$ & $-6.11^{* * *}$ & $-15.84^{* * *}$ & $-6.11^{* * *}$ \\
Observations & $(0.60)$ & $(0.55)$ & $(0.60)$ & $(0.55)$ \\
$R^{2}$ & & & & \\
Number of countries & 0.78 & 0.72 & 0.78 & 0.72 \\
\hline \hline
\end{tabular}

Note: Panel-corrected standard errors in parentheses; $* * * p<0.01, * * p<0.05, * p<0.1$.

Country effects are not displayed in the regression table.

Finally, the robustness of the results was further checked by replacing the Polity IV measure of democracy with the dichotomous 'ACLP' democracy variable ${ }^{81}$ and Bueno de Mesquita et al.'s democracy indicator. ${ }^{82}$

As the results in Table 6 show, replacing the measure of democracy does not change the results reported above. At the stage of early economic development, political regime type does not seem to affect environmental quality. As long as citizens do not strongly demand that their political leaders use the scarce resources available to reduce pollution, democracies seem to be no better stewards of their environment than their autocratic counterparts.

\section{CONCLUSION}

This article set out to examine which factors have the potential to curtail environmental pollution in developing countries, focusing on membership of IGOs. Controlling for economic aspects of globalization, such as trade openness and FDI inflows, I have evaluated whether the inclusion of the political aspect of international integration adds to our understanding of the environmental performance of developing countries.

${ }^{81}$ Alvarez, Cheibub, Limongi and Przeworski, 'Classifying Political Regimes'.

${ }^{82}$ Bueno de Mesquita, Smith, Siverson and Morrow, The Logic of Political Survival. 
More precisely, I have argued that IGOs can act as channels through which developing countries may receive technology and resources necessary to reduce pollution, especially since IGOs also allow for issue linkages. Moreover, IGOs, in addition to increasing the reputational stakes for reneging on agreements, can provide a forum for actors interested in the environment to diffuse knowledge of and influence other countries towards greater environmental protection. The results indeed show that IGO membership is robustly associated with a decrease in both $\mathrm{SO}_{2}$ and $\mathrm{CO}_{2}$ emissions.

Furthermore, and in line with theoretical expectations, my findings demonstrate that in the early stages of economic development political regime type has no independent effect on environmental performance. The reasoning behind this finding, as proposed in this article, is that in the early stages of economic development the citizenry in developing countries will not demand that their governments spend scarce resources on improving environmental quality at the expense of basic needs such as education and health. Without these necessary electoral incentives, however, democratic governments do not seem to care more about their environment than their autocratic counterparts, leading to the results that in the early economic development stage democratic developing countries are no better stewards of their environment than autocratic ones. Finally, with respect to a country's income, the results suggest that an increase in GDP per capita is associated with an increase in pollution levels.

Turning from these more general findings to a more detailed analysis of IGO membership, we obtain more insights on the mechanisms that allegedly link IGO membership to a country's environmental performance. By disaggregating IGO membership according to the function and degree of institutionalization of the organization, I shed light on the theoretical underpinning behind the effect of IGO membership.

As expected, when differentiating IGO membership according to the degree of institutionalization, we see that only organizations that possess some degree of formalization or institutionalization can affect environmental quality in developing countries. Interestingly, however, those organizations that can constrain their member countries the most, i.e. the most institutionalized organizations, are not necessarily the most effective ones. In the case of $\mathrm{CO}_{2}$ emissions, the effect of moderately institutionalized organizations is stronger than the effect of the highly institutionalized organizations. This finding is in line with the explanation that the main mechanisms behind the influence of IGO membership as proposed in the theoretical part - which are technology and knowledge transfer, issue linkage and a broader socialization process favouring environmental protection - might work well as long as the organization has some degree of institutionalization, without necessarily needing to be a highly institutionalized organization.

Disaggregating the influence of IGOs further according to their function allows us to specify empirically which of the theoretically proposed mechanisms could be at play: for example, due to their large thematic scope, the influence of umbrella organizations such as the EU or ASEAN can be read as meaning that some IGOs are successful in connecting different issues. Although countries usually join these umbrella IGOs for economic or political reasons, they are, as a side effect, also influenced by the environmental functions of these organizations. By comparison, the importance of social IGOs in the case of $\mathrm{SO}_{2}$ emissions suggests two different mechanisms. First, these organizations may constitute a good forum for the dissemination of information. Furthermore, through the socialization process that takes place at these fora, these organizations may also act as diffusion channels for the idea of environmental protection as suggested in the literature 
on policy diffusion. ${ }^{83}$ Second, many of these organizations disseminate know-how and technology that is helpful to the environment in general, while primarily aiming at improving or preserving human health or labour conditions. Examples of such organizations would be the WHO, the ILO or research-related organizations such as the International Commission for the Scientific Exploration of the Mediterranean Sea. This latter mechanism of information and know-how transfer could also underlie the influence of economic and nuclear organizations, as these IGOs often seem to be conducive to the provision of technological and financial resources, thereby increasing the capacity of developing countries to improve the quality of the environment.

The implications of this article for the study of public goods provision are twofold: first, it seems meaningful to enlarge the focus of existing studies by including additional aspects of the international system into the analysis. As the empirical analysis of this article indicates, the investigation of trade openness and foreign direct investment, which have been important components of past research on environmental quality, ${ }^{84}$ does not seem to play a crucial role in the environmental performance of developing countries. In contrast, membership in intergovernmental organizations is robustly associated with a reduction in both air pollution and greenhouse gas levels. Second, and in contrast to the findings of existing studies, ${ }^{85}$ political regime type per se does not seem to play a significant role in the environmental performance of developing countries.

Hence, the results suggest that in order to improve the quality of the environment in developing countries it seems most promising to tie these countries into various intergovernmental organizations. This is especially true for those organizations that possess at least some degree of institutionalization and which deal with a wide variety of issues.

${ }^{83}$ Cao, 'Networks of Intergovernmental Organizations and Convergence in Domestic Economic Policies'; Simmons and Elkins, 'The Globalization of Liberalization: Policy Diffusion in the International Political Economy'.

${ }^{84}$ Antweiler, Copeland and Taylor, 'Is Free Trade Good for the Environment?'; Mani and Wheeler, 'In Search of Pollution Havens?'

${ }^{85}$ Neumayer, 'Do Democracies Exhibit Stronger International Environmental Commitment?'; Deacon, 'Dictatorship, Democracy, and the Provision of Public Goods'. 